DOI: doi.org/10.21009/IJLECR.051.02

Received: 20 January 2019

Revised: 1 February 2019

Accepted: 12 March 2019

Published: 30 June 2019

\title{
Designing A Needs-Based English Syllabus for the Undergraduate Islamic Education Study Program at STAI Al Aqidah Al Hasyimiyyah Jakarta
}

\author{
$\operatorname{Jastman}^{1, \mathrm{a})}$, Sri Sumarni ${ }^{1, \mathrm{~b})}$, Darmahusni ${ }^{1, \mathrm{~b})}$ \\ Master Program of English Language Education Study Program, \\ Faculty of Language and Arts \\ State University of Jakarta, East Jakarta ${ }^{1)}$
}

jastman_pmpbi15s2@mahasiswa.unj.ac.id ${ }^{\text {a)}}$,Sri.Sumarni@unj.ac.id ${ }^{\text {b) }}$, darmahusni@unj.ac.id ${ }^{\text {c) }}$

\begin{abstract}
This research aims at designing a Needs-Based English Syllabus for undergraduate Islamic education study program. This study used Research and Development (R\&D) modified model of Dick and Carey which employs three stages to design the Needs-Based English syllabus by doing needs analysis, developing the syllabus and validating the syllabus. The findings reveals that the topics, learning objectives, materials, learning activities and assessments in the existing syllabus related with the Islamic education study program do not appear nor represent the language needs of the undergraduate Islamic education study program at STAI Al Aqidah Al Hasyimiyyah. Therefore, the description in terms of the topics, learning objectives, materials, learning activities and assessments available in the expected syllabus are developed. The final design of the syllabus is the Needs-Based English Syllabus for Islamic education study program is resulted from the integration of two kinds of syllabus namely content-based syllabus and skill-based syllabus with the format that are made up of topics, learning objectives, materials, learning activities and assessments that represent the tasks that should be in line with the topics and learning objectives which are relevant with undergraduate Islamic education study program.
\end{abstract}

Keywords: Syllabus; Needs; Needs-based Syllabus; Islamic Education Study Program; Undergraduate, Al Aqidah Al Hasyimiyyah

These days, university graduates from the field of Islamic education study program in Indonesia prefer to work as a Islamic education teacher in Islamic schools, religious boarding schools and related workplaces that therefore they are demanded to be competent in taking up challenging tasks in their professional field. However, in learning English, they do not have ample opportunity and ideal moments to expose to the English learning due to the their little interest in English (Flowerdew and Peacock (2001:315). At present, the teaching of English at the study program at the universities concentrate on general English similarly that may intended to meet the demands of a general worldwide market and show a reckless lack of attention to the Islamic materials and topics. Additionally, there are some facts from the previous related studies that reflects that the English syllabus for Islamic education study program used in general is conspicuously incompatible for the undergraduate students of Islamic education study program. In the first place, a research conducted by Hendriyani (2017) uncovers the majority of English lecturers inclined to teach general English for different students from different course of study. Another fact found by Muhsinin (2013) that 
the general English is not suitable with the students' needs. Another researcher conducted by Rizal (2013) revealed that $86 \%$ respondents claim that the English language teaching material used in teaching and learning process is not suitable with the needs of the Islamic education undergraduate students since the absence of information related to Islamic education.

The needs analysis conducted to ensure that the course have met the students' needs (Nation and Macalister, 2010:32). Therefore, needs analysis refers to a basis stage in course design in gathering, organizing, analyzing, and reporting relevant information (Richards, 2001:63), to provide validity relevancy, and appropriateness that address the needs of the specific students in terms of learning objectives, teaching methods, and materials in all subsequent course design activities (Richards, 2001:67), (Johns, 1991 in Songhori, 2008 :p. 3), (Iwai et al., 1999, in Songhori, 2008 :p. 2), (AlHamlan \& Baniabdelrahman, 2015:p. 120) and, (Richards, 2001:51-52). Within the process of the needs analysis, Al-Hamlan \& Baniabdelrahman, 2015:p. 120, (Songhori, 2008 :p. 3. \&, Jordan, 2011:22) several approaches to needs analysis that support the research are employed to conduct the needs analysis for assessing the students' needs. First, the target-situation analysis (TSA) is John Munby's approach in Communicative Syllabus Design (1978) that concentrate on the students' needs to be mastered and target level performance at the completion of the English course. Secondly, the present-situation analysis proposed by Richterich and Chancerel (1977:80) is to ensure the students' state of English development of knowledge at the outset of the English course in order to identify the existing syllabus to interpret the strength and weaknesses in language, skills, learning experiences (Songhori, 2008:p. 121), (Robinson, 1991, p. 9).

The review to the existing syllabus showed that its contents, materials, and topics bear no reference to Islamic knowledge more specifically as expected in the related documents the Islamic education study program and sound much more commonplace since it mostly exists General English syllabus. These gaps indicates the absence of the desired needs to study English in order to understand Islamic text written in English and use English in Islamic contexts as expected in the documents. Therefore, the suitability between the syllabus and the students programs is the cause of the failure and success of learning (Strevens, 1988:10-23). Because of the main purpose of this study is to design a needs-based syllabus for the undergraduate students of Islamic education study program at STAI Al Aqidah Al Hasyimiyyah Jakarta, it is significantly necessary to design a more appropriate English syllabus to increase the learning quality at the university as stated in government regulation number 19 year 2005 regarding National Education Standards Article 20 that the syllabus include at least the learning objectives, materials, teaching method, sources of learning, and assessment. Furthermore, it entails the design of an English syllabus that based on the students' language needs of the Islamic education study program.

\section{METHOD}

This current research applies the Research and Development ( $R$ and D) with qualitative approach. Dick and Carey (2015) mentions ten phases for designing a syllabus. That is, (1) identify instructional goal (s), (2) conduct instructional analysis, (3) analyse learners and contexts, (4) write performance objectives, (5) develop assessment instruments, (6) develop instructional strategy, (7) develop and select materials, (8) design and conduct the formative evaluation of instruction, (8) revise instruction, and (10) design and conduct summative evaluation. The steps are simplified and modified into three stages by classifying them in terms of similarity and functions. The step 1 serves as the needs assessment process. The steps 2,3,4,5,6,7,8 serves as the development stage. The step 9, and 10 serves as the validation stages. These stages shortened since the consideration of the step 3,4,5,6,7,8 has been done in step 2 and the step 9 done in step 10. Eventually, the modification result in three steps. The following table will illustrate types of $R$ and $D$. 


\begin{tabular}{lll}
\hline $\begin{array}{c}\text { Planning of the Needs } \\
\text { Analysis }\end{array}$ & Syllabus Development & Syllabus Validation \\
\hline Setting up goals & $\begin{array}{l}\text { Specifying the contents } \\
\text { and learning experience } \\
\text { Selecting, classifying, } \\
\text { Assessing needs }\end{array}$ & Evaluating \\
& $\begin{array}{l}\text { Producing the syllabus } \\
\text { the needs (of materials, } \\
\text { activities, and tasks) }\end{array}$ & \\
\hline
\end{tabular}

TABLE 1. Research and Development proposed by Dick and Carey (2015:6-8)

In accordance with the purposes of this present study and the above discussion, the research is finally designed based on the following three- stage model seen in figure 3.1. The model eliminates the stage of (2) Conduct instructional analysis (3) Analyse learners and contexts (4) Write performance objectives, (5) Develop assessment instruments. (6) Develop instructional strategy since they have been represented by the stage (8) Develop and Select Instructional materials. Finally, the stage (9) Revise the instruction eliminated since it has been done in stage (10) Design and conduct summative evaluation. Therefore, it can be inferred that from the concept of the Dick and Carey model that the step of (a) needs assessment is a part of the others stage 1, (b) syllabus development that covers the stages 2,3,4,5,6,7,8 done in stage 2, (c) the syllabus validation covers the stages 9 and 10 done in stages 10 since they have similar functions.

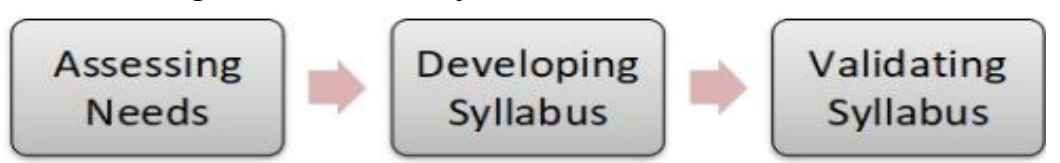

Figure 1. Research design model based on Dick and Carey (2015)

\begin{tabular}{|l|l|l|l|}
\hline \multicolumn{1}{|c|}{ Types } & \multicolumn{1}{c|}{ Statement of Research Questions } \\
$\begin{array}{l}\text { Sub } \\
\text { Research } \\
\text { Question } \\
1\end{array}$ & $\begin{array}{l}\text { How are the topics, learning } \\
\text { objectives, materials, activities and } \\
\text { assessment in the existing syllabus } \\
\text { of Islamic education study program } \\
\text { at the institute of STAI Al Aqidah Al } \\
\text { Hasyimiyyah Jakarta? }\end{array}$ & $\begin{array}{l}\text { Find the existing } \\
\text { syllabus of the Islamic } \\
\text { education study } \\
\text { program }\end{array}$ & $\begin{array}{l}\text { Need } \\
\text { Analysis }\end{array}$ \\
\hline $\begin{array}{l}\text { Sub } \\
\text { Research } \\
\text { Question } \\
2\end{array}$ & $\begin{array}{l}\text { How are the topics, learning } \\
\text { objectives, materials, activities and } \\
\text { assessment expected by the Islamic } \\
\text { education study program at the } \\
\text { institute of STAI Al Aqidah Al } \\
\text { Hasyimiyyah Jakarta documents? }\end{array}$ & $\begin{array}{l}\text { Find the related } \\
\text { documents as the } \\
\text { expected syllabus of the } \\
\text { Islamic education study } \\
\text { programs }\end{array}$ & $\begin{array}{l}\text { Proposed } \\
\text { Syllabus }\end{array}$ \\
\hline $\begin{array}{l}\text { Sub } \\
\text { Research } \\
\text { Question } \\
3\end{array}$ & $\begin{array}{l}\text { How do the topics, learning } \\
\text { objectives, materials, activities, and } \\
\text { assessments in the existing syllabus } \\
\text { comply with those of the Islamic } \\
\text { education study program at the } \\
\text { institute of STAI Al Aqidah Al } \\
\text { Hasyimiyyah Jakarta documents? }\end{array}$ & $\begin{array}{l}\text { Comply the results of } \\
\text { the analysis of both the } \\
\text { existing syllabus and } \\
\text { related document }\end{array}$ & Design \\
\hline
\end{tabular}




\begin{tabular}{|c|c|c|c|c|}
\hline $\begin{array}{l}\text { Main } \\
\text { Research } \\
\text { Question }\end{array}$ & $\begin{array}{l}\text { How is the needs-based English } \\
\text { syllabus for the undergraduate } \\
\text { students of Islamic education study } \\
\text { program at at the institute of STAI } \\
\text { Al Aqidah Al Hasyimiyyah? }\end{array}$ & b) & $\begin{array}{l}\text { The compliance } \\
\text { results are } \\
\text { employed to } \\
\text { propose the } \\
\text { syllabus } \\
\text { Conduct the focus } \\
\text { group discussion } \\
\text { for experts } \\
\text { validation with } \\
\text { likert scale } \\
\text { instruments } \\
\text { The revision } \\
\text { developed to } \\
\text { design a needs- } \\
\text { based English } \\
\text { syllabus }\end{array}$ & $\begin{array}{l}\text { Syllabus } \\
\text { Design }\end{array}$ \\
\hline
\end{tabular}

TABLE 2. Research Questions and the Stages of Research Design

\section{RESULTS AND DISCUSSION}

The results and discussion deals with the existing syllabus for the undergraduate Islamic education study program. The existing English syllabus used at the Islamic education study program of the Islamic institute of STAI Al Aqeedah Al Hasyimiyyah is the English syllabus that serves as general subject with 14 sessions. Based on the data analysis, the existing topics, learning objectives, materials, activities and assessment are seen as the following.

\begin{tabular}{|c|c|c|c|c|c|}
\hline Weeks & Topics & $\begin{array}{c}\text { Learning } \\
\text { Objectives }\end{array}$ & Materials & Activities & Assessments \\
\hline 1 & $\begin{array}{l}\text { Introducing } \\
\text { ourselves }\end{array}$ & \multirow{10}{*}{$\begin{array}{l}\text { 1) Verbal and } \\
\text { written } \\
\text { 2)Professional } \\
\text { world } \\
\text { 3)English } \\
\text { Grammar }\end{array}$} & $\begin{array}{l}\text { giving personal } \\
\text { information }\end{array}$ & \multirow{10}{*}{$\begin{array}{l}\text { 1)Lecture } \\
\text { 2)Question } \\
\text { and answer } \\
\text { 3)Discussion } \\
\text { 4)Presentation } \\
\text { 5)Writing } \\
\text { report }\end{array}$} & \multirow{10}{*}{$\begin{array}{l}\text { 1)Task } \\
\text { 2)Presentation } \\
\text { 3)Presence } \\
\text { 4)Participati }\end{array}$} \\
\hline 2 & $\begin{array}{l}\text { Introducing } \\
\text { others }\end{array}$ & & $\begin{array}{l}\text { introduce } \\
\text { others }\end{array}$ & & \\
\hline 3 & $\begin{array}{l}\text { Routine } \\
\text { activities }\end{array}$ & & $\begin{array}{l}\text { simple present } \\
\text { tense }\end{array}$ & & \\
\hline 4 & $\begin{array}{l}\text { Describing } \\
\text { things }\end{array}$ & & adjectives & & \\
\hline 5 & $\begin{array}{l}\text { Asking for } \\
\text { and giving } \\
\text { directions }\end{array}$ & & $\begin{array}{l}\text { preposition of } \\
\text { places }\end{array}$ & & \\
\hline 6 & $\begin{array}{l}\text { Our capital } \\
\text { city }\end{array}$ & & $\begin{array}{l}\text { reading } \\
\text { comprehension }\end{array}$ & & \\
\hline 7 & & & & & \\
\hline 8 & Preference & & preference & & \\
\hline 9 & $\begin{array}{l}\text { We love } \\
\text { dangdut }\end{array}$ & & $\begin{array}{l}\text { reading } \\
\text { comprehension }\end{array}$ & & \\
\hline 10 & Reporting & & $\begin{array}{l}\text { simple past } \\
\text { tense and } \\
\text { preposition of } \\
\text { time }\end{array}$ & & \\
\hline
\end{tabular}




\begin{tabular}{|c|c|c|c|}
\hline 11 & $\begin{array}{l}\text { Making } \\
\text { arrangement }\end{array}$ & future tense & \\
\hline 12 & $\begin{array}{l}\text { Is this } \\
\text { progress }\end{array}$ & $\begin{array}{l}\text { reading } \\
\text { comprehension } \\
\& \text { discussion }\end{array}$ & \\
\hline 13 & $\begin{array}{l}\text { Business } \\
\text { Matters }\end{array}$ & $\begin{array}{l}\text { reading } \\
\text { comprehension } \\
\& \text { discussion }\end{array}$ & \\
\hline 14 & $\begin{array}{l}\text { Business } \\
\text { Letters }\end{array}$ & $\begin{array}{l}\text { forms and } \\
\text { differences }\end{array}$ & \\
\hline \multirow[t]{2}{*}{15} & $\begin{array}{l}\text { Application } \\
\text { letters }\end{array}$ & $\begin{array}{l}\text { forms and } \\
\text { terms }\end{array}$ & \\
\hline & & & Final test \\
\hline
\end{tabular}

TABLE 3. Data Analysis of Existing Syllabus

The existing syllabus of English discussed in terms of the existing topics, existing learning objectives, existing materials, existing learning activities and existing assessments. Firstly, the existing topics available in the existing syllabus covers language functions, grammar, texts, letters which are not relevant with the Islamic education. Therefore, the topics are not relevant with the Islamic education program. They are much more appropriate with general English and business English. Therefore, they are not conversant with nor relevant with the needs of the study program of Islamic education. Secondly, the learning objectives do not adequately represent the target to be accomplished at the completion of the course. They are expressed redundantly without using active verbs and do not emphasize the measurable competences more specifically that relate with the Islamic education. The four learning objectives are not adequate to cover 14 meetings respectively since they sound too common. Thirdly, the materials available in the existing English syllabus are not directly stated. However, it can inferred that they are located together with the topics in the same components and cover language functions, basic English grammar, and learning activities. These materials bear resemblances at the early sessions of the existing syllabus. The materials represent the language needs in General English context and do not represent the language needs in Islamic education study program since the contents are relevant with the Islamic education study program. Fourthly, the learning activities in the existing syllabus are lecturing and questions and answer session, discussion, presentation, and writing report. Nevertheless, the learning activity for writing a report is inappropriate as the learning activities for the 14 meeting for syllabus of general subjects. The learning activities are suitable for the most part in the existing English syllabus. Moreover, writing a report is inappropriate for the time allocation of 14 meetings. All the learning activities should describe competencies. The learning activities are not provided in each meetings. Finally, the existing assessments presented in the existing syllabus are made up of tasks, presentation, presence and participation, mid-term test, and final test are not elaborated more comprehensively with sentences in order to be clear what competences and performance to asses specifically. All assessments are not located appropriately for each meetings. The absence of explicit directions regarding whether students have to read or write make the users difficult to determine the kinds of competences and performances to be evaluated.

Based on the data analysis presented on the appendix 4. the expected syllabus of the undergraduate Islamic education study program is the one termed as the needs-based syllabus. In this study the needs is represented by the institution expectation which are represented the campus profile, campus brochure, website sources. The expected topics, learning objectives, materials, activities and assessment are seen as the following. 


\begin{tabular}{|l|l|l|l|l|l|}
\hline Needs & \multicolumn{1}{|c|}{ Topics } & $\begin{array}{l}\text { Learning } \\
\text { Objectives }\end{array}$ & \multicolumn{1}{|c|}{ Materials } & Activities & Assessments \\
\hline $\begin{array}{l}\text { Campus } \\
\text { Profile }\end{array}$ & $\begin{array}{l}\text { Islamic } \\
\text { Knowledge }\end{array}$ & $\begin{array}{l}\text { Advanced in } \\
\text { Islamic } \\
\text { knowledge }\end{array}$ & Islamic teaching & $\begin{array}{l}\text { Carry out } \\
\text { Islamic } \\
\text { teachings }\end{array}$ & $\begin{array}{l}\text { Understand } \\
\text { Islamic } \\
\text { knowledge }\end{array}$ \\
\hline $\begin{array}{l}\text { Campus } \\
\text { Website }\end{array}$ & $\begin{array}{l}\text { Islamic } \\
\text { knowledge, } \\
\text { education, } \\
\text { and } \\
\text { working } \\
\text { work as } \\
\text { Islamic } \\
\text { teacher }\end{array}$ & $\begin{array}{l}\text { Skilled in } \\
\text { working } \\
\text { world as } \\
\text { Islamic } \\
\text { teacher }\end{array}$ & $\begin{array}{l}\text { Islamic education } \\
\text { world \& working } \\
\text { world }\end{array}$ & $\begin{array}{l}\text { Equip with } \\
\text { Islamic } \\
\text { education }\end{array}$ & $\begin{array}{l}\text { Understand } \\
\text { Islamic } \\
\text { education }\end{array}$ \\
\hline $\begin{array}{l}\text { Campus } \\
\text { Brochure }\end{array}$ & $\begin{array}{l}\text { Islamic } \\
\text { education } \\
\text { knowledge } \\
\text { \& working } \\
\text { world as } \\
\text { Islamic } \\
\text { teacher }\end{array}$ & $\begin{array}{l}\text { Skilled in } \\
\text { working } \\
\text { world } \\
\text { demands (as } \\
\text { Islamic } \\
\text { teacher) }\end{array}$ & $\begin{array}{l}\text { Islamic education } \\
\text { world \& working } \\
\text { world }\end{array}$ & $\begin{array}{l}\text { Develop } \\
\text { knowledge in } \\
\text { the field of } \\
\text { Islamic } \\
\text { religion }\end{array}$ & $\begin{array}{l}\text { Apply } \\
\text { Islamic } \\
\text { knowledge } \\
\text { education }\end{array}$ \\
\hline
\end{tabular}

TABLE 4. Data Analysis of the Expected Syllabus

The expected topics, learning objectives, materials, activities and assessment are discussed in detail to meet the expected standard of the syllabus. Firstly, the topics in the existing documents are inferred that based on the such statements, it suggests that the expectation of English language teaching the teaching of English that teach Islamic knowledge and educational knowledge of Islam that consequently the topics incorporated in the needs-based English syllabus should be relevant with Islamic knowledge as expected by the Islamic education study program in terms of reading skills and writing skills. Secondly, the learning objectives in the existing documents are excellent in Islamic knowledge as stated in the campus profile, competent in education and working environments of Islamic education teacher as stated in the campus website, and be skilled for the needs of working environments of Islamic education teacher as mentioned in the campus brochure. Therefore, it can be interpreted that the expectation of Islamic education study program of STAI Al Aqidah Al Hasyimiyyah translated into the learning objective that students are able to show understanding of the Islamic texts written in English and use English in Islamic context. Thirdly, the materials in the existing documents are to teach English is to teach Islamic knowledge that will be useful after graduation once they work as Islamic education teacher by teaching students to read and write Islamic texts. For this reason the topics should emphasize the teaching of Islamic knowledge. Fourthly, the teaching and learning activities in the expected syllabus are not obviously described, that is, carry out Islamic teaching as represented in the campus profile. Equipping students with education as indicated in the campus website, developing knowledge in the field of Islamic religion, as can be seen in the campus campus brochure. Therefore, it can inferred that the expectation of Islamic education program of the STAI Al Aqidah Al Hasyimiyyah Jakarta is in order to provide students with Islamic knowledge by teaching reading and writing activities. Finally, the assessment is not explicitly stated in the existing documents that the assessments which are appropriate with the Islamic education study program are those that measure the students knowledge of Islam. 
The existing English syllabus complies with the expected syllabus to yield a first rough draft of the needs-based English syllabus produced based on the results of the comparison and adjustment prescribed. In the first place, the topics consist of introducing ourselves, introducing others, routine activities, describing things, asking for and giving directions, our capital city, preference, we love dangdut, reporting, making arrangement, is this progress, business matter, application letters that are not relevant with Islamic education. However, the expected topics are Islamic knowledge and Islamic education. The gap is the topics in the existing syllabus mostly provides the topics which are general English that comprise language functions, basic grammar. They are relevant with the study program of Islamic education. The proposed topics namely, the revelation of the Quran, Islamic creed, the status of the sunnah in Islam, why did god create mankind, prophet Muhammad, performing hajj, the performance of the umrah, missed salah, wudoo, the dangers of backbiting others, and displaying gratitude.

Secondly, the learning objectives in the existing syllabus described directly but they are lengthy and inadequate. However, they do not address the competencies should be achieved by the students at the completion of the course. The existing learning objectives consist of verbal and written, Professional work, and English Grammar. The expected learning objectives consist of advanced in Islamic knowledge, competent in educational word \& working world as Islamic teacher, and skilled in the working world as Islamic teacher. The gap is they do not address the competencies should be achieved by the students at the completion of the course. The proposed competencies include are identify the main idea and the supporting details of the first revelation of the Quran text, identify 5 pillars of Islam, find the main ideas from material the forms and benefits of tawheed, summarize important points related with from the text of the major Shirk and its manifestation and how they connect with Islamic creed, Identify three hadiths that correspond to misguidance of those who are satisfied with the Qur'an over Sunnah, define the meaning of worship in relation with the essential purpose of mankind's creation, rewrite a short descriptive text related to the Prophet Muhammad, describe the Hajj rituals pilgrimage, summarize the text related to the pilgrimage of the performance of Umrah, summarize points of the passage related to the zakah recipients, describe the prayer of a traveler that correspond to making Qada' the prayer, summarize the text into a short procedural text of the steps for performing Wudoo, differentiate the true Islamic personality with the personality of gossiping others, summarize ideas from the text of being generous and prefers other over oneself, read the text of both paradise and deeds are from grace of Allah 's blessings and summarize the text related with Allah's blessings can never be truly repaid.

Thirdly, the existing syllabus consist of giving personal information, expressions to introduce others, simple present, adjectives, preposition of places, reading comprehension, preference, reading comprehence, simple past, future tense, reading comprehension and discussion, reading comprehension and discussion, forms and differences, forms and terms. The expected materials namely related with Islamic teachings. The gaps are they do not address the materials related with the needs of the Islamic education program of the Islamic education study program at the Islamic institute of Al Aqidah Al Hasyimiyyah Jakarta. The materials cover a great amount of grammar contents without including those relevant with Islamic knowledge and education. The proposed materials consists of the first revelation of the Quran, the second revelation of the Quran, 5 pillars of islam, 6 pillars of faith, the forms and benefits of tawheed, major shirk and its manifestation, the misguidance of those who are satisfied with the Qur'an over sunnah, the need for the sunnah in order to understand the Qur'an, the meaning of worship, the need for worship, the companions of the prophet Muhammad, description of Muhammad, description of hajj rituals, the performance of the umrah, zakah paid at the end of ramadhan, zakah recipients, the prayer of a traveler, combining two prayers, things that break wudoo, the steps for performing wudoo, ban of gossiping about 
others, being generous and prefers other over oneself, both paradise and deeds are from grace of Allah, and Allah's blessings can never be truly repaid.

Fourthly, the existing learning activities comprises pedagogical activities related with Islamic education namely lecture, question and answer, discussion, presentation, report. The expected learning activities namely carry out the teaching of Islamic knowledge, equip with the knowledge of Islamic education, develop in the field of Islamic religion. The gap is the existing learning activities do not address how the are done by the students of Islamic education study program and share similarities with the general syllabus the proposed learning activities are identify the main idea and the supporting details of the first revelation of the Quran text, identify 5 pillars of Islam, find the main ideas from material the forms and benefits of tawheed, summarize important points related with from the text of the major Shirk and its manifestation and how they connect with Islamic creed, Identify three hadiths that correspond to misguidance of those who are satisfied with the Qur'an over Sunnah, define the meaning of worship in relation with the essential purpose of mankind's creation, Rewrite a short descriptive text related to the Prophet Muhammad, describe the Hajj rituals pilgrimage, summarize the text related to the pilgrimage of the performance of Umrah, summarize points of the passage related to the zakah recipients, describe the prayer of a traveler that correspond to making Qada' the prayer, summarize the text into a short procedural text of the steps for performing Wudoo, differentiate the true Islamic personality with the personality of gossiping others, summarize ideas from the text of being generous and prefers other over oneself, read the text of both paradise and deeds are from grace of Allah 's blessings and summarize the text related with Allah's blessings can never be truly repaid

Finally, the existing syllabus describes the assessment directly namely tasks, presentation, presence, participation, mid-term test, final test. The expected assessments namely understanding and applying Islamic knowledge and Islamic education. The gap is the assessments are presented in general without clear description how the assessment done and what the students should do and performances to be evaluated. Therefore, the assessments should measure the competences and the performances of the students to read and write the texts related with Islamic knowledge. The proposed assessments are identify the main idea and the supporting details of the first revelation of the Quran text, identify 5 Pillars of Islam, find the main ideas from material the forms and benefits of Tawheed, Summarize important points related with from the text of the major Shirk and Its manifestation and how they connect with Islamic creed, Identify three hadiths that correspond to misguidance of those who are satisfied with the Qur'an over Sunnah, define the meaning of worship in relation with the essential purpose of mankind's creation, rewrite a short descriptive text related to the Prophet Muhammad, describe the Hajj rituals pilgrimage, summarize the text related to the pilgrimage of the performance of Umrah, summarize points of the passage related to the zakah recipients, describe the prayer of a traveler that correspond to making Qada' the prayer, summarize the text into a short procedural text of the steps for performing Wudoo, differentiate the true Islamic personality with the personality of gossiping others, summarize ideas from the text of being generous and prefers other over oneself, read the text of both paradise and deeds are from grace of Allah 's blessings and summarize the text related with Allah's blessings can never be truly repaid.

The third stage of the modified Dick and Carry model is validating the first draft of the proposed syllabus through the focus group discussion. The first draft of the Needs-Based English Syllabus are available in appendix 4 designed in 2019. It comprises course description and course outline. The proposed syllabus validated in the form of the focus group discussion that involves the three validators from internal English lecturers of the state university of Jakarta and one expert from English lecturer from the STAI Al Aqidah Al Hasyimiyyah Jakarta by using the instruments of evaluation rating scale Likert scale to measure the quality of the syllabus based on the indicators to validate whether or not it can be applied. The review are given by those experts feedback as the 
feedback and recommendation to revise the weaknesses of proposed syllabus. The validation has the resulted in validators' recommendations for the revision of the proposed syllabus. First, the topics should guide to the contents while tasks would be addressed to the how learning will be done in order that the materials can be digested by students in line with the competences. Therefore, the revision for this feedback is the topics are adjusted to guide the the contents stated in the learning activities to inform the competencies measured. Secondly, in terms of the learning objectives, it is recommended to check wording of CLO, proficiency, discipline, definition and its contents, the amount of CLOs in the syllabus, CS, the verbs and the nouns should be checked again. In terms of the the course description, it covers the learning objectives and learning outcomes-sub-learning outcomes. The revision for this feedback is the wording of CLOs has changed into learning objective and the learning outcomes are located on each sessions by using Bloom's taxonomy. The learning outcomes (LOs) are located in each meetings. The learning objective is placed in the area of the course description.

Another feedback obtained are the materials given in the English course should teach Islamic values in the form of reading comprehension and texts. Additionally, the sources should be complete in terms of the chapter and the year of publications. The materials for teaching English for the Islamic education study program are concentrated in teaching English with the contents provided with texts for reading comprehension. The revision for this feedback is the information related with the sources have been comprehensively provided especially in terms of chapter and the year of publications. The topic and materials address the text for reading comprehension. Fourth, the learning activities such as encouragement and deterrence are not necessary. The learning activities should represent the task which is relevant for their students. the activities should be continued and then what and how the learning activities for writing. The revision is the learning activities are described in sentences and appropriate activities represent the task which is relevant for the students. The final feedback is the assessments of the skills of reading and writing that will be measured are still not appeared. The assessments should be in line with the topics, stated objectives, and activities so revise the assessments. The revision for this feedback is the assessments are written in the forms of sentences with the appropriate actions verbs that are measurable. The assessments have been adjusted to be aligned with the topics, learning objectives, and activities.

The discussions of the first research question deal with the findings to this research question shows that existing syllabus at the STAI Al Aqidah Al Hasyimiyyah employed in even semester year 2019 was not designed based on needs in terms of the topics, learning objectives, materials, learning activities, and assessment. First, the topics in the existing syllabus are ambiguous and inappropriate, and it is more appropriate for general English. Secondly, the learning objectives in the existing syllabus include verbal and written, professional world and English grammar use lengthy and redundant sentences. Four learning objectives are inadequate and have not determined to be be used in what meetings. The measurable wording are not used in the learning objectives learning. The action verbs should be measurable and specific as stated in Bloom's Taxonomy. Thirdly, the materials are derived from general English and the two of them comes from business English and none of them are relevant to Islamic education study program. Fourthly, The learning activities available in the existing syllabus are lecture, question and answer, discussion, presentation, writing report are not comprehensively described. They should represent the task which is relevant for students performance of the learning activities for reading and writing described in sentences and appropriate activities that represent the task which is relevant for the students. Finally, the assessments in the form of task, presentation, presence, and participation in the existing syllabus do not address the appropriate activities and materials very clearly without obvious description regarding how the assessment conducted and what performances to assessed. The assessment should be written in the form of sentences. 
The discussions of the second research question reveal the findings that the expected syllabus in terms of the topics, learning objectives, materials, learning activities, and assessment. Firstly, the statement that describes the topics derived from campus profile website is educational knowledge that can be inferred Islamic educational knowledge. The statements that indicate the topics in the campus brochure are educational knowledge and working environments. Consequently, the expected topics include the revelation of the Quran, Islamic creed, fruits of faith, the purpose of mankind creation and so on and so forth. Secondly, the expectation of Islamic studies program of STAI Al Aqidah Al Hasyimiyyah translated into the learning objective that students are able to students are expected to show understanding of the Islamic texts written in English and use English in Islamic context. For example, students are able to define the meaning of worship in relation with the purpose of mankind creation, students are able to write a short descriptive text related to the Prophet Muhammad.. Thirdly, the materials expected by the Islamic education study program are the educational knowledge of Islam result in the teaching of Islamic knowledge. For instance, the forms and benefits of Tawheed, major shirk and its manifestation, virtues of belief in Allah,, and so on and so forth. Fourthly, the expectation of Islamic education program of the STAI Al Aqidah Al Hasyimiyyah Jakarta is in order to provide students with Islamic knowledge by teaching reading and writing activities. For example, read for specific information the text regarding the forms and benefits of Tawheed, summarize important points related with from the text of the major shirk and its manifestation, and so on. Finally, the assessments which are appropriate with the Islamic education study program are those that measure the students knowledge and skills of reading and writing regarding Islamic issues. For example, read for specific information the text regarding the forms and benefits of Tawheed, summarize important points related with from the text of the major Shirk and Its manifestation.

The discussion of the third research question deals with the findings to this research questions indicated the results of analysis of the comply between the results of analysis of existing syllabus and and those of related documents in terms of the topics, learning objectives, materials, learning activities, and assessment. Firstly, the topics in the existing syllabus which are ambiguous and more appropriate for teaching general English should be redesigned based on the demands and expectation of the Islamic education study program of the STAI Al Aqidah Al Hasymiyyah Jakarta as stated in the related documents that the statement that describes the topics derived from campus profile website is educational knowledge that can be inferred Islamic educational knowledge. For this reason, the existing English syllabus requires revision and development in terms of the topics, learning objectives, materials, learning activities and assessment since they are not relevant with the contexts and needs of the Islamic education study program. Secondly, the lengthy and redundant sentences and limited number of learning objectives revised in order to be used in each meeting with measurable and specific wording of the action verbs should be written as stated in Bloom's Taxonomy. Thirdly, the materials demanded in the expected syllabus are organized to be in line with the educational knowledge of Islam as stated in the related documents. Fourthly, the learning activities as expected in the syllabus to teach students to read and write related with Islamic texts. Finally, the assessments are written in the form of sentences to address the appropriate activities and materials very clearly with obvious description regarding how the assessment conducted and what performances to assessed to measure the students knowledge and skills of reading and writing regarding Islamic issues.

The discussions of the main research question deal with the final product of the needs-based English syllabus is made up of course description, and the course outline namely the sessions, topics, learning objectives (reading and writing), materials, activities, and assessments, and time allocation that resulted from the integration of two kinds of syllabus namely content-based syllabus and skill-based syllabus with the time allotment of 100 minutes per session of 14 sessions including 
the one session for mid-term test and 1 other session for the final test. The 2 credits $(2$ skills) are provided for the English course. Therefore, the syllabus is designed for the needs-based syllabus for semester 2 syllabus hat concentrate on the teaching of in reading and writing in order to be able to understand and to use English in Islamic contexts.

\section{CONCLUSION}

The existing English syllabus requires revision and development in terms of the topics, learning objectives, materials, learning activities and assessment since they are not relevant with the contexts and needs of the Islamic Education Study Program. Hopefully, this study can bridge the needs of the undergraduate students of Islamic education study program by designing a needs-based English syllabus that relevant with the Islamic contexts at the STAI Al Aqidah Al Hasyimiyyah Jakarta.

\section{REFERENCES}

Al-Hamlan, S.A., and Baniabdelrahman, A.A. (2015). A Needs Analysis Approach to EFL Syllabus Development for Second Grade Students in Secondary Education in Saudi Arabia: A Descriptive Analytical Approach to Students' Needs. American International Journal of Contemporary Research Vol. 5, No. 1

Dick, W and Carrey, L. (2015). The Systematic Design Instruction. Eight Edition, the United States of America, Pearson

Flowerdew, J. and Peacock, M. (2001). The EAP curriculum: Issues, methods and challenges. In John Flowerdew and Matthew Peacock (eds) Research Perspectives on English for Academic Purposes. Cambridge: Cambridge University Press.

Hendriani, S. 2017. Teaching English For Specific Purposes (Esp) For Islamic Higher Education Students (pp. 701-710) State Institute For Islamic Studies Batusangkar, West Sumatera.

Iwai, T., Kondo, K., Limm, S. J. D., Ray, E. G., Shimizu, H., and Brown, J. D. (1999). Japanese language needs analysis. Available at: http://www.nflrc.hawaii.edu/Networks/NW13/NW13.pdf

Jordan, R. R. 2011. English for Academic Purposes - A guide and resource book for teachers. Cambridge: Cambridge University Press.

Nation, I.S.P and Macalister, J. 2011. Case Studies in Language Curriculum Design. New York. Routledge.

Muhsinin. (2013). Developing English for Islamic Studies for Students of Islamic Education Department Mataram State Institute for Islamic Studies (IAIN Mataram). National Seminar of Research Results Thesis dan Disertastion-PPS Unnes

Munby, J. (1978). Communicative syllabus design, Cambridge: Cambridge University Press.

Richards, J. C. (2002). Curriculum Development in Language Teaching. Cambridge: Cambridge University Press.

Richterich, R., and Chancerel, J.L. (1977). Identifying the needs of adults learning a foreign language. Oxford: Pergamon Press.

Rizal, S. 2013. Developing a Model of Islamic Educational Studies based Reading Comprehension Instructional Material through Schema Theory Approach for Tarbiyah Students of IAIN of Bengkulu”: SELT 2014, Padang, June 11-12, 2014 (p. 402-408). Bengkulu. State Institute for Islamic Studies of Bengkulu (IAIN Bengkulu)

Robinson, P. (1991). ESP today: A practitioner's guide. Prentice Hall. UK: Prentice Hall International (UK) Ltd.

Songhori, M.H. 1998. Introduction to Needs Analysis. English for Specific Purposes World, Issue 4. 
Strevens, P. (1988). ESP After Twenty Years : A re-appraisal. In M. Tickoo (Ed.), ESP: State of the Art. Singapore: SEAMEO Regional Centre. 